\title{
STINK BUG POPULATION FLUCTUATION AND CONTROL IN SOUR PASSION FRUIT ORCHARDS IN SOUTHERN BRAZIL ${ }^{1}$
}

\author{
NOEL ALVES RIBEIRO ${ }^{2}$, JOATAN MACHADO DA ROSA ${ }^{3 *}$, CLÁUDIO ROBERTO FRANCO $^{2}$, MARI INÊS \\ CARISSIMI BOFF ${ }^{2}$
}

\begin{abstract}
Sour passion fruit (Passiflora edulis Sims, 1818) crops in Brazil are drawing attention due to the national production, and the increasing consumption of this fruit as fresh and processed products. However, fruit losses due to damages caused by stink bugs (Hemiptera: Coreidae) are concerning to fruit growers in southern Brazil. The objective of this study was to evaluate the population fluctuation and control of stink bugs in P. edulis crops grown in the 2013-2014 and 2014-2015 crop seasons in Araquari, SC, Brazil, using natural and synthetic insecticides. The stink bug population was evaluated using the $0.25 \mathrm{~m}^{2}$ frame technique. The evaluations were carried out weekly during the two crop seasons. The species and distribution of stink bugs in the different parts of the plant were evaluated. The insecticides and rates used were: Neenmax (azadirachtin $1.0 \%$ ) at $10 \mathrm{~mL} \mathrm{~L}^{-1}$; Orobor $\mathrm{N} 1\left(\mathrm{~N}\right.$-citric acid $1.0 \%+0.20 \% \mathrm{~B}$ ) at $2 \mathrm{~mL} \mathrm{~L}^{-1}$; and Decis $25 \mathrm{EC}$ (deltamethrin $2.5 \%$ ) at $1 \mathrm{~mL} \mathrm{~L}^{-1}$, diluted in aqueous solution. Specimens of three stink bug species where found: $86 \%$ Diactor bilineatus (Hemiptera: Coreidae); 13.5\% Holhymenia histrio (Hemiptera: Coreidae), and 0.5\% Nezara viridula (Hemiptera: Pentatomidae). The D. bilineatus species presented higher frequency, constancy, and dominance during the evaluated crop seasons; $64 \%$ of the stink bugs were found on fruits, $18.5 \%$ on leaves, $7.3 \%$ on floral buds, $5.8 \%$ on flowers, and $4.4 \%$ on branches. The use of azadirachtin or deltamethrin was efficient to reduce the stink bug infestation and the number of $P$. edulis withered fruits.
\end{abstract}

Keywords: Insect pest management. Passiflora edulis. Hemiptera. Chemical control.

\section{FLUTUAÇÃO POPULACIONAL E CONTROLE DE PERCEVEJOS EM POMAR DE MARACUJAZEIRO-AZEDO NO SUL DO BRASIL}

\begin{abstract}
RESUMO - O cultivo do maracujazeiro-azedo Passiflora edulis (Sims, 1818) vem obtendo destaque na fruticultura nacional devido ao aumento do consumo tanto da fruta fresca, como processada. Contudo, perdas pelo ataque de percevejos (Hemiptera: Coreidae) vêm preocupando fruticultores da região sul do Brasil. O objetivo deste estudo foi avaliar a ocorrência e o controle de percevejos em pomar de maracujazeiro-azedo $P$. edulis, através da utilização de inseticidas naturais e sintéticos nas safras de 2013/14 e 2014/15 em Araquari/ SC. A ocorrência de percevejos foi estudada através de amostragens utilizando a técnica do quadro de madeira com dimensão de $0,25 \mathrm{~m}^{2}$. As avaliações foram realizadas semanalmente durante as duas safras. As espécies e a distribuição dos percevejos nas diferentes partes da planta foram quantificadas. Os inseticidas utilizados foram: Neenmax (Azadiractina 1,0\%) na dose de $10 \mathrm{~mL} / \mathrm{L}$; Orobor N1 (Ácido cítrico N 1,0\% + B 0,20\%) 2 $\mathrm{mL} / \mathrm{L}$; Decis 25 EC (Deltametrina 2,5\%) $1 \mathrm{~mL} / \mathrm{L}$, diluídos em solução aquosa. Foram observados exemplares de três espécies de percevejos, sendo 86\% Diactor bilineatus (Hemiptera: Coreidae); 13,5\% Holhymenia histrio (Hemiptera: Coreidae) e $0,5 \%$ de Nezara viridula (Hemiptera: Pentatomidae). D. bilineatus apresentou alta frequência, constância e dominância durante as safras avaliadas. Os percevejos encontravam-se $64 \%$ sobre os frutos, $18,5 \%$ sobre as folhas, 7,3\% sobre os botões florais, 5,8\% sobre as flores e 4,4\% sobre os ramos. A pulverização com Azadiractina e Deltametrina foram eficientes para reduzir a infestação de percevejos e ocorrência de frutos murchos no pomar de maracujazeiro-azedo.
\end{abstract}

Palavras-chave: Manejo integrado de pragas. Passiflora edulis. Hemiptera. Controle químico.

\footnotetext{
*Corresponding author

${ }^{1}$ Received for publication in 02/08/2019; accepted in 09/02/2019.

Paper extracted from the doctoral thesis of the first author.

${ }^{2}$ Department of Agronomy, Universidade do Estado de Santa Catarina, Lages, SC, Brazil; noelalvesribeiro@hotmail.com - ORCID: 00000002-0480-3009, claudio.franco@udesc.br-ORCID: 0000-0001-7944-0671, mari.boff@udesc.br - ORCID: 0000-0003-1700-8837.

${ }^{3}$ Department of Basic Pathology, Universidade Federal do Paraná, Curitiba, PR, Brazil; joatanmachado@gmail.com - ORCID: 0000-0002$1680-7525$.
} 


\section{INTRODUCTION}

Passion fruit (Passiflora sp.) is one of the main fruit species grown in Brazil (ASSUNÇÃO et al., 2015), where the sour passion fruit (Passiflora edulis Sims, 1818) is the most important commercial species of this fruit. P. edulis plants produce large fruits with acid-orange and aromatic pulp (BEZERRA et al., 2016). The harvested area in the country in 2016 was 49,889 hectares, with mean yield of $14.1 \mathrm{Mg} \mathrm{ha}^{-1}$ (ABF, 2018). The Northeast is the main producing region of passion fruit, with $64.9 \%$ of the Brazilian production; and the South region accounts for $6.6 \%$ of the national production (IBGE, 2016). Passion fruit orchards are mainly implemented by family farmers because the crop provides fast economic return and source of income (MELETTI, 2011).

Stink bugs are the main pests in passion fruit crops in Brazil (RUGGIERO et al., 1996; FANCELLI; ALMEIDA, 2006). According to Oliveira and Frizzas (2014), the main species that damage passion fruit plants are: Diactor bilineatus (Fabr., 1803), Holhymenia clavigera (Herbst, 1784), Holhymenia histrio (Fabr., 1803), Leptoglossus gonagra (Fabr., 1775), Leptoglossus stigma (Herbst, 1784), and Anisoscelis foliacea marginella (Dallas, 1852), (Hemiptera: Coreidae). Damages caused by Nezara viridula (Hemiptera: Pentatomidae) were also found for sweet passion fruit ( $P$. alata Curtis, 1788 ) in the Federal District after soybean (Glycine $\max$ L., 1737) crops (ICUMA et al., 2001).

Adult stink bugs feed on leaves, twigs, and fruits; and nymphs prefer flower buds and new fruits. Damaged fruits become smaller, withered, and deformed, and have dark punctuations at feeding sites (FADINI; SANTA-CECÍLIA, 2000). Deformations in fruits decrease their quality for fresh marketing (FANCELLI; ALMEIDA, 2002).

Despite few synthetic insecticides are approved for chemical control, it is the most used method for insect pest control in passion fruit (FANCELLI; ALMEIDA, 2006). Cultural control is an alternative, which consists in the collection and elimination of stink bug eggs, nymphs, adults, and their alternative hosts (MACHADO et al., 2017). The use of stink bug-resistant passion fruit genotype is also recommended as a control strategy (BALDIN; BOIÇA JUNIOR, 1999; CAETANO et al., 2000). Another option for controlling these pests is the use of botanical insecticides, such as citrus and neem (Azadirachta indica) oils, which present low toxicity to mammalian species and high persistence in the environment (ISMAN, 2008).

Considering the damages caused by stink bugs in sour passion fruit ( $P$. edulis) orchards and the little information on the efficiency of control methods, the objective of this study was to evaluate the population fluctuation and control of stink bugs, and the control efficiency of natural and synthetic insecticides in the control of this insect pest in passion fruit orchards.

\section{MATERIAL AND METHODS}

The experiment was conducted in a 0.51 ha sour passion fruit orchard, with 860 hybrid plants from crosses of the ovulado, amarelo cerrado, and gigante cerrado lines grown in trellising system, in Araquari, Santa Catarina (SC), Brazil (26021'56"S, $48^{\circ} 42^{\prime} 26^{\prime \prime} \mathrm{W}$, and mean altitude of $4 \mathrm{~m}$ ). The climate of the region is $\mathrm{Cfa}$, humid subtropical, according to the Köppen classification, with annual average temperature of $20{ }^{\circ} \mathrm{C}$, relative air humidity of $85 \%$, and annual rainfall of 1,700 to $1,900 \mathrm{~mm}$ (PEEL; FINLAYSON; MCMAHON, 2007).

The orchard's surroundings were composed of Atlantic Forest remnants with presence of other fruit species, such as Malpighia emarginata (DC, 1828) (acerola), Persea americana (Miller, 1768) (avocado), Citrus sinensis (L., 1753) Osbeck (orange), Punica granatum (L., 1753) (pomegranate), Musa acuminata (L., 1753) (banana), Psidium guajava (L., 1753) (guava), and Carica papaya (L., 1753) (papaya).

The stink bug population fluctuation was evaluated from January 2014 to June 2015, comprising the 2013-2014 and 2014-2015 crop seasons. The evaluations were made weekly, in the afternoon, when the passion fruit flowers were open, using a similar methodology to that proposed by Caetano et al. (2000). A $50 \times 50 \mathrm{~cm}\left(0.25 \mathrm{~m}^{2}\right)$ wooden frame was fixed on one side of the trellis, with the aid of a metal hook in the center of the plants and at $1.5 \mathrm{~m}$ from the ground. The stink bug species were quantified through this frame, considering the distribution of these insects in the different organs of the plants and the injuries caused by their infestation.

The stink bugs were collected, placed in bottles with 70\% alcohol, and sent to the Entomology Laboratory of the Federal University of Pará (UFPA) to determine their species. The frequency, constancy, and dominance of species of stink bugs were determined by using the formulas described by Silveira Neto et al. (1976). The frequency $(\mathrm{F})$ was determined by $F=(n i / N) \times 100$, where $F$ is the frequency of the species $i$ in percentage; $n i$ is the number of individuals of the species $i$; and $N$ is the total number of individuals collected in the sampled area, classifying the species $i$ as infrequent, frequent, or very frequent. The constancy was determined by the formula $C=(p \times$ 100) / $N$, where $C$ is the percentage of constancy; $p$ is the number of collections containing the species $i$; and $N$ is the total number of collections. 
The species were classified according to the classification proposed by Silveira Neto et al., (1976), which considers constant the species that are found in more than $50 \%$ of the collections, accessory when present in $25 \%$ to $50 \%$ of the collections, and accidental when present in less than $25 \%$ of the collections. Dominance was determined by $D=$ Nmax / NT, where $D$ is the dominance, Nmax is the number of individuals of the most abundant species, and $N T$ is the total number of individuals in the sample.

The use of natural and synthetic insecticides was evaluated in the same area and time as the monitoring of the stink bug populations. The treatments consisted of Neenmax $\quad(1.0 \%$ azadirachtin) at a rate of $10 \mathrm{~mL}$ of the commercial product per liter of water; Orobor N1 (Citric acid N $1.0 \%+\mathrm{B} 0.20 \%$ ) at $2.0 \mathrm{~mL}$ of the commercial product per liter of water; Decis 25 EC (deltamethrin $2.5 \%$ ) at $1.0 \mathrm{~mL}$ of the commercial product per liter of water; and a control treatment containing only water. A randomized block experimental design was used, with plots consisting of ten plants.

The treatments were applied fortnightly in the mornings. The products were applied using a 16liters backpack sprayer Model SP161, Guarany ${ }^{\circledR}$, maximum pressure of $6.9 \mathrm{kPa}(75 \mathrm{psi})$, and flow rate of $600 \mathrm{~mL} \mathrm{~min}^{-1}$ with average speed of $3 \mathrm{~km} \mathrm{~h}^{-1}$, and a spray volume rate of $700 \mathrm{~L} \mathrm{ha}^{-1}$. The percentage of withered fruits was recorded during the harvest period in each treatment to determine the effectiveness of the insecticides in the control of stink bugs.

The obtained data were subjected to analysis of variance, and the means were compared by the Tukey's test at 5\% significance level. The insect mortality values found were corrected by Abbott's formula (1925) the values expressed as percentage and the direct count were transformed to arcsen $\sqrt{ }$ $(x / 100)$ and $\sqrt{ }(x+0.5)$, respectively. The statistical analysis was performed with the aid of the DSAASTAT 1.101 program (ONOFRI, 2010).

\section{RESULTS AND DISCUSSION}

Two-hundred six adult stink bugs were sampled in the passion fruit orchard during the study period, whose species were: $86 \%$ Diactor bilineatus (Fabr., 1803), 13.5\% Holhymenia histrio (Fabr., 1803 ), and $0.5 \%$ Nezara viridula (L., 1758). The species with high frequency, constancy, and dominance was $D$. bilineatus; the frequency of the other species was classified low, accidental, or not dominant (Table 1). The occurrence of these stink bug species may vary according to the location and passion fruit species. In Jaboticabal, SP, Brazil, the most abundant stink bug species in passion fruits of $P$. edulis f. flavicarpa was $L$. zonatus (Hemiptera: Coreidae), and in $P$. laurifolia was $L$. gonagra (Hemiptera: Coreidae); in Passiflora giberti were $A$. foliacea marginella and $H$. histrio (Hemiptera: Coreidae) (CAETANO et al., 2000).

Regarding the plant parts where the stink bugs species were found, $64 \%$ was on fruits, $18.5 \%$ on leaves, $7.3 \%$ on flower buds, $5.8 \%$ on flowers, and $4.4 \%$ on fruit branches. The occurrence of stink bugs in five passion fruit species found by Caetano et al. (2000) in Jaboticabal, SP, was predominantly $(65.6 \%)$ on fruits. In the present study, the stink bugs were mainly on flowers and fruits in development, which directly affects the quantity and quality of fruits.

In general, insect population distribution is connected to host plant availability, which provide them with shelter, food, and mating site. There were guava trees around the evaluated orchard, whose fruits are hosts of $H$. clavigera (LUNZ et al., 2006). However, this phytophagous stink bug species was not found in the samplings of the present study. There is a hypothesis that the absence of certain stink bug species may be related to the antibiosis factors found in some passion fruit species, such as $P$. edulis for the stink bugs of the species $H$. histrio (BALDIN; BOIÇA JÚNIOR, 1999) and L. gonagra (CAETANO et al., 2000).

Table 1. Stink bug species sampled in passion fruit plants (Passiflora edulis) in the 2013-2014 and 2014-2015 crop seasons, Araquari, SC, Brazil.

\begin{tabular}{ccccc}
\hline Species & Total & Frequency & Constancy & Dominancy \\
\hline Diactor bilineatus & 177 & High & Constant & yes \\
Holhymenia histrio & 28 & Low & Accidental & no \\
Nezara viridula & 1 & Low & Accidental & no \\
\hline
\end{tabular}

The peak population of stink bugs occurred in March in both crop seasons (Figure 1). Stink bugs were present in the passion fruit orchard during the whole evaluation period. However, in June (end of the harvest period) to October, the number of specimens found in the evaluated areas decreased (Figure 1). Decreases in temperature (CAETANO et al., 2000) and presence of natural enemies 
(FANCELLI; ALMEIDA, 2002) are factors that can decrease the stink bug population in passion fruit orchards. However, the absence of reproductive structures such as flowers, flower buds, and fruits (main food sources), especially from June to October, was the main factor for the decrease in the stink bug population (Figure 1).

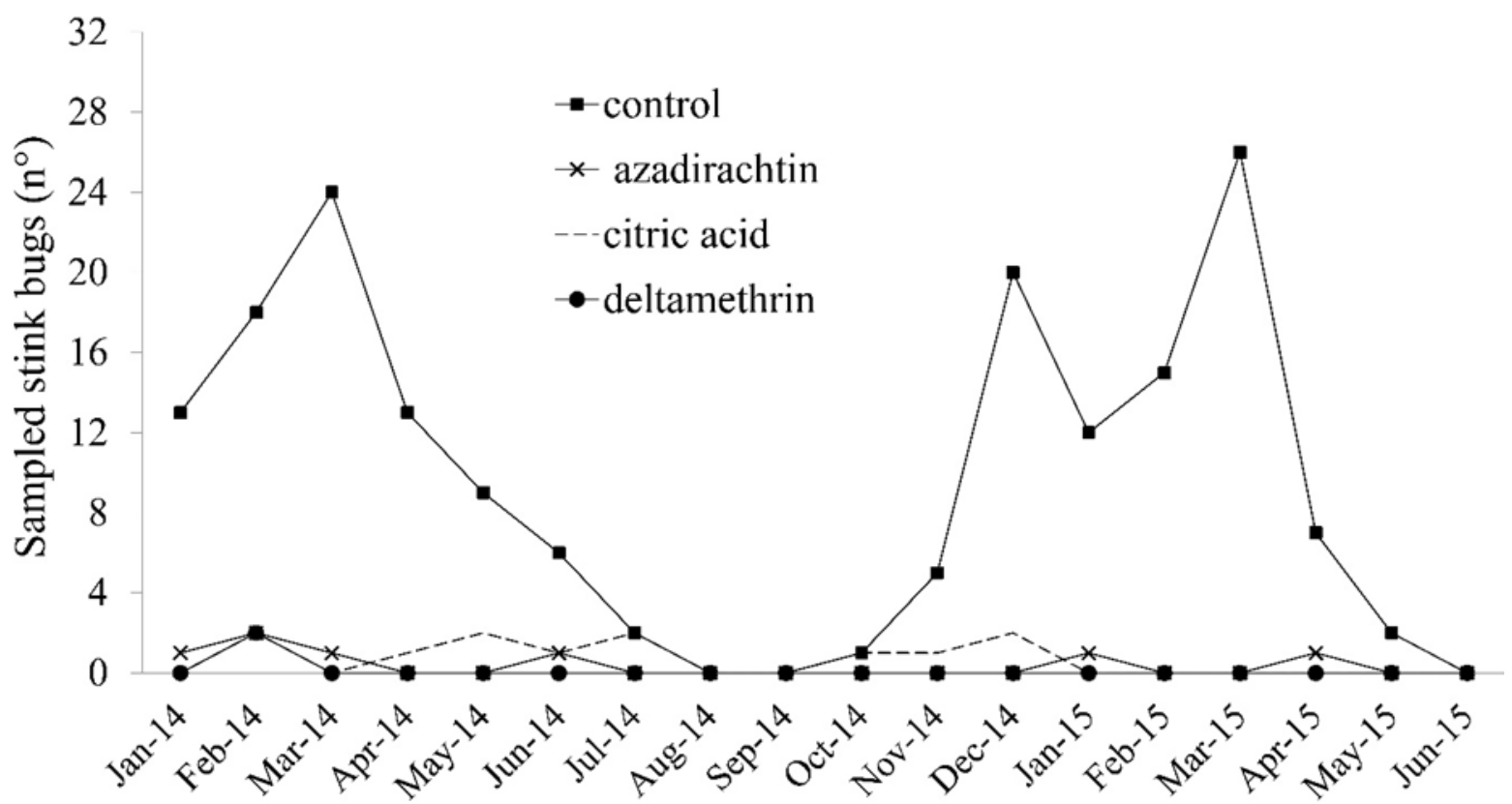

Figure 1. Stink bug population fluctuation in passion fruit trees (Passiflora edulis) treated with botanical and synthetic insecticides in the 2013-2014 and 2014-2015 crop seasons, Araquari, SC, Brazil.

The stink bug population increased considerably from October and November 2014, shortly after the beginning of flowering of the passion fruit, showing population peak in March (Figure 1). Similarly, Caetano et al. (2000) evaluated sour passion fruit orchards in Jaboticabal, SP, and found increases in stink bug population from December to July, with population peak in March.
The stink bug population fluctuation was influenced by the application of natural or synthetic insecticides and differed from the control treatment. The plants in the treatment without insecticides presented variation of 8 to 28 stink bugs per month during the passion fruit production period, October to June (Figure 1). In this period, the number of stink bugs on plants treated with insecticides was less than one per month, presenting significant difference when compared to the control treatment (Table 2).

Table 2. Percentage of withered fruits with symptoms of stink bug bites, number of stink bugs found, percentage of stink bugs control, and yield of passion fruit (Passiflora edulis) in the 2013-2014 and 2014-2015 crop seasons, Araquari, SC, Brazil.

\begin{tabular}{|c|c|c|c|c|c|}
\hline \multirow[t]{2}{*}{ Treatments } & \multicolumn{2}{|c|}{ Withered fruits $(\%)$} & \multirow[t]{2}{*}{ Number of stink bugs } & \multirow{2}{*}{$\begin{array}{c}\text { Control } \\
(\%)\end{array}$} & \multirow{2}{*}{$\begin{array}{l}\text { Fruit yield } \\
\left(\mathrm{Mg} \mathrm{ha}^{-1}\right)\end{array}$} \\
\hline & $2013-2014$ & $2014-2015$ & & & \\
\hline Control & $23.0 \pm 5.2 \mathrm{a}$ & $35.8 \pm 6.4 \mathrm{a}$ & $9.6 \pm 8.5 \mathrm{a}$ & - & $7.8 \mathrm{~b}$ \\
\hline Azadirachtin & $9.5 \pm 2.5 \mathrm{~b}$ & $5.5 \pm 2.1 \mathrm{c}$ & $0.4 \pm 0.6 \mathrm{bc}$ & $95.0 \mathrm{a}$ & $10.2 \mathrm{a}$ \\
\hline Citric Acid & $17.8 \pm 2.5 \mathrm{a}$ & $15.3 \pm 3.8 \mathrm{~b}$ & $0.7 \pm 0.8 \mathrm{~b}$ & $93.0 \mathrm{ab}$ & $9.2 \mathrm{ab}$ \\
\hline Deltamethrin & $6.5 \pm 4.2 \mathrm{~b}$ & $4.5 \pm 2.1 \mathrm{c}$ & $0.1 \pm 0.5 \mathrm{c}$ & $99.0 \mathrm{a}$ & $11.0 \mathrm{a}$ \\
\hline CV (\%) & 14.5 & 13.0 & 49.13 & - & - \\
\hline
\end{tabular}

Means followed by the same letter in the column are different by the Tukey's test $(p<0.05)$. CV $(\%)=$ coefficient of variation.

Regarding the control efficiency of the insecticides, the stink bugs population on plants in the treatments were $93 \%$ lower for the citric acid, 95\% lower for the azadirachtin, and $98 \%$ lower for the deltamethrin, when compared to the control treatment. Thus, no significant differences in control efficiency were found when comparing the treatments containing natural or synthetic insecticides (Table 2).

The lower incidence of stink bugs on passion fruit plants treated with azadirachtin and deltamethrin resulted in a $23 \%$ and $29 \%$ higher fruit yield, respectively, when compared to the control treatment (Table 2). The treatments with azadirachtin 
and deltamethrin resulted in significantly lower percentage of withered fruits due to stink bug damages in both crop seasons; and the one with citric acid differed from the control treatment only in the 2014-2015 crop season (Table 2). These results show that both synthetic and natural insecticides can decrease the percentage of fruit damaged by stink bugs, ensuring the fruit quantity and quality of passion fruit orchards for both fresh and industry markets. However, plants treated with citric acid showed higher percentage of withered fruits when compared to those treated with azadirachtin or deltamethrin, in both crop seasons (Table 2).

According to Lebedenco et al. (2007), the use of chemical control of insect pests by applying synthetic insecticides may result in significant higher production cost, especially when used without other control strategies. Another disadvantage of this method is that these insecticides usually have low selectivity to natural enemies, as occurs for deltamethrin (HOHMANN et al., 2010; STECCA et al., 2017)

The natural citric acid-based insecticides used in integrated pest management (IPM) programs present selectivity for the parasitoid Trichogramma pretiosum (LUCKMANN et al., 2014). In the present study, despite the use of citric acid did not result in a satisfactory control of stink bug damages, it contributed to the reduction of the insect population.

Botanical insecticides have been shown to have low toxicity to mammals and low persistence in agroecosystems (ISMAN, 2008). Neem-based compounds applied in vineyards have been found to be less toxic to certain natural enemies, such as $T$. pretiosum (MORANDI FILHO et al., 2006). However, Ndakidemi, Mtei and Ndakidemi (2016) showed that these compounds present different levels of toxicity to natural enemies and pollinators, and reported that neem-based biopesticides may, in some situations, reduce parasitism rates of natural enemies and cause lethal and sublethal effects to predators and pollinators. Contrastingly, Badshah et al. (2017) showed that pure oil and seed extract of neem are proven to be less toxic to natural enemies than synthetic insecticides. Moreover, Ratnakar et al. (2017) reported that organophosphates and pyrethroids were significantly more toxic to pollinators than neem oil, according to the toxicity classes stablished by the International Organization for Biological and Integrated Control of Noxious Animals and Plants (IOBC).

Therefore, chemical compounds for controlling insect pests in IPM systems need to be used with caution, regardless their synthetic or natural origin. Moreover, constant studies are needed to optimize the concentrations to be used, the application times, and the residual effects of these compounds on natural enemies and pollinators. The optimization of these factors makes possible to create and improve more sustainable ways of using these chemical compounds, especially those of natural origin.

\section{CONCLUSIONS}

The stink bug species Diactor bilineatus is constant, frequent, and dominant in the sour passion fruit (Passiflora edulis) crops in Araquari, SC, Brazil. D. bilineatus specimens are found from October (beginning of flowering) to June (end of harvesting), with population peak in March. Application of azadirachtin or deltamethrin is effective to control stink bug infestation and to reduce the occurrence of $P$. edulis withered fruits.

\section{REFERENCES}

ABBOTT, W. S. A method of computing the effectiveness of an insecticide. Journal of Economic Entomology, v. 18, n. 2, p. 265-267, 1925.

ANUÁRIO BRASILEIRO DE FRUTICULTURA ABF. Santa Cruz do Sul: Gazeta, 2018. 88 p. Disponível em: $<$ http://www.editoragazeta.com.br/ produto/anuario-brasileiro-da-fruticultura/>. Acesso em: 02 ago. 2019.

ASSUNÇÃO, M. P. et al. Seleção individual de plantas de maracujazeiro azedo quanto à qualidade de frutos via REML/BLUP. Revista Caatinga, v. 28 , n. 2, p. 57-63, 2015

BALDIN, E. L. L.; BOIÇA JÚNIOR, A. L. Desenvolvimento de Holhymenia histrio (Fabr.) (Hemiptera: Coreidae) em frutos de cinco genótipos de maracujazeiro (Passiflora spp.). Anais da Sociedade Entomológica do Brasil, v. 28, n. 3, p. 421-427, 1999.

BADSHAH, H. et al. Can toxicants used against cotton mealybug Phenacoccus solenopsis be compatible with an encyrtid parasitoid Aenasius bambawalei under laboratory conditions? Environmental Science and Pollution Research, v. 24, n. 6, p. 5857-5867, 2017.

BEZERRA, L. M. C. et al. Cultivo de maracujáamarelo no estado de São Paulo: principais características a partir do levantamento das unidades de produção agropecuária, ano-safra 2007/2008. Informações Econômicas, v. 46, n. 2, p. 35-46, 2016.

CAETANO, A. C. et al. Avaliação da ocorrência sazonal de percevejo em cinco espécies de maracujazeiro utilizando dois métodos de 
amostragem. Bragantia, v. 59, n. 3, p. 45-51, 2000.

FADINI, M. A. M.; SANTA-CECÍlIA, L. V. C. Manejo integrado de pragas do maracujazeiro. Informe Agropecuário, v. 21, n. 206, p. 29-33, 2000 .

FANCELLI, M.; ALMEIDA, A. Insetos-praga e seu controle, in: LIMA, A. A. (Ed.) Maracujá Produção: aspectos técnicos. Cruz das Almas: Embrapa Mandioca e Fruticultura, 2002. v. 1, cap. 10, p. $57-66$

FANCELLI, M.; ALMEIDA, A. de. Percevejos (Hemiptera: Coreidae) in: LUNZ et al. Reconhecimento dos Principais Insetos-Praga do maracujazeiro. 1. ed. Belém, PA: Embrapa Amazônia Oriental, 2006. 36 p. (Documentos Embrapa Amazônia Oriental, 245).

HOHMANN, C. L. et al. Selectivity of neem to Trichogramma pretiosum riley and Trichogrammatoidea annulata De Santis (Hymenoptera: Trichogrammatidae). Neotropical Entomology, v. 39, n. 6, p. 985-990, 2010.

INSTITUTO BRASILEIRO DE GEOGRAFIA E ESTATÍSTICA - IBGE. Pesquisa de orçamentos familiares e produção agrícola municipal/2016. Disponível em: <https://biblioteca.ibge.gov.br/ visualizacao/periodicos/66/pam_2016_v43_br.pdf $>$. Acesso em: 13 dez. 2018.

ICUMA, I. M. et al. Pragas da cultura do maracujá-doce no Distrito Federal. 1. ed. Brasília, DF: Embrapa Cerrados, 2001. 3 p. (Comunicado técnico Embrapa Cerrados, 47).

ISMAN, M. B. Perspective botanical insecticides: for richer, for poorer. Pest Management Science, v. 64, n. 1, p. 8-11, 2008.

LEBEDENCO, A. et al. Métodos de controle de lepidópteros na cultura do tomateiro (Lycopersicon esculentum Mill.). Acta Scientiarum Agronomy, v. 29, n. 3, p. 339-344, 2007.

LUCKMANN, D. et al. Seletividade de produtos naturais comerciais a Trichogramma pretiosum (Riley, 1879) (Hymenoptera: Trichogrammatidae). Revista Ceres, v. 61, n. 6, p. 924-931, 2014.

LUNZ, A. M. et al. Reconhecimento dos principais insetos-praga do maracujazeiro. 1. ed. Belém, PA: Embrapa Amazônia Oriental, 2006. 36 p. (Documentos Embrapa Amazônia Oriental, 245). ed. Brasília, DF: Embrapa, 2017. 94 p.

MELETTI, L. M. M. Avanços na cultura do maracujá no Brasil. Revista Brasileira de Fruticultura, v. 33, sup., p. 83-91, 2011.

MORANDI FILHO, W. J. et al. Ação de produtos naturais sobre a sobrevivência de Argyrotaenia sphaleropa (Meyrick) (Lepidoptera: Tortricidae) e seletividade de inseticidas utilizados na produção orgânica de videira sobre Trichogramma pretiosum Riley (Hymenoptera: Trichogrammatidae). Ciência Rural, v. 36, n. 4, p. 1072-1078, 2006.

NDAKIDEMI, B.; MTEI, K.; NDAKIDEMI, P. A. Impacts of synthetic and botanical pesticides on beneficial insects. Agricultural Sciences, v. 7, n. 6, p. 364, 2016.

OLIVEIRA, M. A. S.; FRIZZAS, R. M. Principais pragas do maracujazeiro amarelo (Passiflora edulis $f$. flavicarpa Degener) e seu manejo. 1. ed. Planaltina, DF: Embrapa Cerrados, 2014. 43 p. (Documentos Embrapa Cerrados, 323).

ONOFRI, A. DSAASTAT a new Excel ${ }^{\circledR}$ VBA macro to perform basic statistical analyses of field trials. Department of Agriculture and Environmental Sciences, University of Perugia, Italy, 2010.

PEEL, M. C.; FINLAYSON, B. L.; MCMAHON, T. A. Update world map of the Koeppen-Geiger Climate classification. Hydrology and earth system sciences discussions, v. 4, n. 2, p. 439-473, 2007

RATNAKAR, V. et al. Contact Toxicity of Certain Conventional Insecticides to European Honeybee, Apis mellifera Linnaeus. International Journal of Current Microbiology and Applied Sciences, v. 6, n. 8, p. 3359-3365, 2017.

RUGGIERO, C. et al. Maracujá para exportação: aspectos técnicos da produção. 1. ed. Brasília, DF: Embrapa-SPI, 1996. 64 p.

SILVEIRA NETO, S. et al. Manual de Ecologia dos insetos. 1. ed. São Paulo, SP: Agronômica Ceres, 1976. $419 \mathrm{p}$.

STECCA, C. et al. Selectivity of insecticide use in soybean crop to the predator Podisus nigrispinus (Hemiptera: Pentatomidae). Semina: Ciências Agrárias, v. 38, n. 6, p. 3469-3480, 2017.

MACHADO, C. D. F. et al. Guia de identificação e controle de pragas na cultura do maracujazeiro. 1

This work is licensed under a Creative Commons Attribution-CC-BY https://creativecommons.org/licenses/by/4.0 